\title{
PERMAINAN TRADISIONAL SEBAGAI SARANA UNTUK MENINGKATKAN JIWA NASIONALISME
}

\author{
Varina Handayani, Dinie Anggraeni Dewi \& Yayang Furi Furnamasari \\ Universitas Pendidikan Indonesia \\ Email: varinahandayani@upi.edu
}

\begin{abstract}
Abstrak
Globalisasi merupakan proses perkembangan ilmu pengetahuan dan teknologi untuk menghasilkan pemikiran yang baru serta perubahan kepribadian manusia. Globalisasi memiliki dampak yang baik dan juga tidak baik sehingga kita harus dapat memilah mana yang baik dan dapat dicontoh serta membuang hal-hal yang tidak baik. Indonesia merupakan negara kepulauan yang memiliki banyak suku dan juga kebudayaan, pada saat ini kebudayaan yang telah lama ada mulai terkikis seiring berjalannya waktu itu dan juga merupakan salah satu dampak dari globalisasi, maka dari itu kita sebagai warga negara Indonesia harus dapat meningkatkan kecintaan terhadap kebudayaan nasional, melestarikan kebudayaan nasional, serta meningkatkan jiwa nasionalisme.
\end{abstract}

Kata Kunci: Globalisasi, Permainan Tradisional, Nasionalisme

\begin{abstract}
Globalization is a process of developing science and technology to produce new thoughts and changes in human personality. Globalization has both good and bad impacts, so we must be able to sort out what is good and can be imitated and discard things that are not good. Indonesia is an archipelagic country that has many tribes and cultures, at this time the culture that has existed for a long time is starting to erode over time and is also one of the impacts of globalization, therefore we as Indonesian citizens must be able to increase our love for national culture, preserving national culture, and increasing the spirit of nationalism.
\end{abstract}

Keywords: Globalization, Traditional Games, Nationalism

\section{PENDAHULUAN}

Globalisasi merupakan suatu proses perkembangan ilmu pengetahuan dan teknologi untuk menghasilkan pemikiran yang baru serta perubahan kegiatan manusia yang mempengaruhi kepribadian nya (Febriyanti \& Dewi, 2021). Globalisasi memiliki dampak yang baik contoh nya seperti mempermudah kita untuk bertukar kabar dengan sanak saudara yang jauh serta mempermudah kita untuk memperoleh suatu informasi, Namun globalisasi tidak hanya memiliki dampak baik ada juga beberapa dampak buruk (tidak baik) yaitu mudahnya budaya luar yang masuk kedalam negeri kita tercinta tanpa adanya filter sehingga sering kali masyarakat kita khususnya generasi muda melupakan budaya nasional Indonesia salah satunya ialah Permainan Tradisional (Ulfah et al., 2021).
Indonesia adalah negara berbentuk kepulauan yang memiliki banyak suku dan juga kebudayaan (Isnaini \& Dewi, 2021). Kebudayaan tersebut tentunya beragam seperti tari tradisional, pakaian adat, rumah adat, bahasa daerah termasuk permainan tradisional (Sofiyatul \& Dewi, 2021). Namun dengan adanya Globalisasi tersebut kebudayaan tradisional yang telah ada sejak zaman dulu kini terkikis dan mulai tergantikan seiring berjalannya waktu (Hikmah \& Dewi, 2021).

Pada saat ini anak-anak mulai melupakan kebudayaan tradisional dan lebih memilih kebudayaan luar yang belum tentu memiliki pengaruh baik terkhusus dalam permainan (Setyawati et al., 2021). Terdapat perbedaan yang sangat jauh antara permainan tradisional dan permainan modern, karena permainan modern biasanya menggunakan media 
digital dan terdapat banyak ragam permainan yang dapat kita mainkan hanya dengan berdiam diri dan tidak perlu bergerak (Pertiwi \& Hidayah, 2021). Sedangkan dalam permainan tradisional biasanya terdapat beberapa aktivitas gerak yang tentunya mengandung nilai moral seperti jujur, bertanggung jawab, saling membantu satu sama lain, bekerja sama dalam team, melatih kemampuan serta membangun jiwa nasionalisme melalui syair dalam bahasa daerah yang dinyanyikan dalam beberapa permainan (Bella et al., 2021).

Terlupakan nya kebudayaan nasional Indonesia merupakan suatu permasalahan penting yang harus kita perhatikan karena apabila dibiarkan maka kebudayaan tradisional kita akan terlupakan dan menghilang seiring berjalan nya waktu. Maka dari itu kita harus dapat berupaya agar masyarakat terkhusus generasi muda mengetahui dan juga dapat membantu melestarikan kebudayaan tradisional kita agar tidak hilang tergerus oleh zaman. (Suryawan, 2020) (Chilwanto et al., 2021)

\section{METODE PENELITIAN}

Pada kesempatan kali ini penulis, Menggunakan metode Kualitatif atau pendekatan deskriptif dengan cara mengumpulkan data yang sudah ada yang kemudian diolah untuk membentuk suatu artikel yang tersusun secara lengkap berdasarkan hasil pemikiran dan analisis dari data yang di peroleh melalui study literatur.

\section{HASIL PENELITIAN DAN PEMBAHASAN Hasil Penelitian}

\begin{tabular}{llr}
\multicolumn{1}{c}{ Mulyana } & (1990) & (Dewantara \& \\
Nurgiansah, & 2021a) & menyatakan \\
nasionalisme & merupakan & kesadaran \\
bernegara atau semangat nasional, yang \\
menuntut perwujudan nilai-nilai dasar \\
yaitu kepentingan bersama dan
\end{tabular}

menghindari legalisasi kepentingan pribadi.Nasionalisme pada hakekatnya adalah suatu ideologi negara. Konsep nasionalisme sendiri lahir ketika Ben Anderson mengungkapkan gagasannya tentang masyarakat khayalan (imagined communities). Menurut Anderson nasionalisme adalah: "... it is an imagined political community that is imagined as bothinherently limited and sovereign".

Nasionalisme dapat diartikan juga sebagai Cinta tanah air. Cinta tanah air dapat disebutkan juga sebagai rasa kebanggaan,menghargai menghormati dan loyalitas tinggi dari setiap individu kepada negara tempat ia tinggal. Banyak sekali cara untuk mencintai tanah air salah satunya dengan ikut melestarikan kebudayaan tradisional seperti melestarikan seni tari tradisional, musik tradisional, permainan tradisional dan lain sebagainya.

Subagiyo (hlm.6) dalam (Dewi Sarah et al., 2021) menyatakan permainan tradisional merupakan suatu permainan yang merupakan tradisi masyarakat suatu daerah, permainan ini dapat menjadi suatu ide yang baik untuk mengembangkan pendidikan anak serta untuk mempertahankan budaya nasional (Artobatama, 2018) (Rachman, Nurgiansah, et al., 2021). Permainan tradisional memberikan alternatif yang kaya dengan nilai budaya (culture), dan bahkan mungkin saat ini sudah hampir punah jika tidak dipelihara dan dikembangkan Interaksi yang terjadi pada saat anak melakukan permainan tradisional memberikan kesempatan kepada anak untuk mengembangkan kemampuan sosial, melatih kemampuan bahasa, dan kemampuan emosi (Kurniati: 2016) (Rachman, Ryan, et al., 2021).

\section{Pembahasan}

Dewasa ini kebudayaan tradisional kita mulai terlupakan karena adanya 
globalisasi, Globalisasi merupakan suatu proses perkembangan ilmu pengetahuan dan teknologi untuk menghasilkan pemikiran yang baru serta perubahan kegiatan manusia yang mempengaruhi kepribadian salah satu kebudayaan yang mulai menghilang atau berkurang salah satunya ialah permainan tradisional.

Permainan merupakan suatu kegiatan yang harus bisa menciptakan ataupun menimbulkan rasa senang bagi pelakunya. Bermain merupakan salah satu sarana yang berguna untuk perkembangan dan juga memberikan kesempatan kepada anak untuk belajar mengenai dirinya sendiri orang lain dan lingkungan, bermain juga merupakan suatu cara untuk memberikan kebebasan kepada anak dalam berimajinasi untuk mengeksplorasi dan menciptakan sesuatu (Nurgiansah \& Al Muchtar, 2018). Dalam melakukan suatu permainan tentunya ada beberapa ketentuan atau syarat yang tentunya menjadi acuan apakah permainan tersebut bisa di jalankan atau tidak. Ketentuan atau syarat itu diantaranya:

a. Permainan dilakukan setidaknya paling minimal 2 orang

b. Bersifat perlombaan

c. Terdapat pemenang dan juga orang yang kalah

d. Permainannya terjadi secara teratur

e. Memiliki peraturan khusus

Permainan tradisional adalah salah satu fokus yang beredar dan terjadi secara turun-temurun permainan tradisional pada dasarnya merupakan permainan yang tumbuh di masyarakat setempat. Permainan tradisional memiliki beberapa nilai-nilai budaya yang terkandung. Menurut Sukirman dharma Mulya nilainilai yang terkandung dalam permainan tradisional ialah: melatih sikap mandiri, Aya misalnya berani mengambil keputusan, bertanggung jawab, jujur, sikap dikontrol oleh lawan, kerjasama, saling membantu dan saling menjaga, membela kepentingan kelompok, berjiwa demokrasi, patuh terhadap peraturan, penuh perhitungan, ketepatan berpikir dan bertindak, tidak cengeng, berani, bertindak sopan dan bertindak luwes, dalam permainan tradisional juga alat-alat yang digunakan cukup sederhana dengan memanfaatkan benda-beda yang ada di sekitar.

Menurut Ki Hadi sukatno (Nurgiansah, 2018), permainan tradisional dapat dikelompokkan menjadi lima macam, yaitu:

1. Permainan yang bersifat menirukan perbuatan orang dewasa

2. Permainan untuk mencoba kekuatan dan kecakapan

3. Permainan untuk melatih panca indera

4. Permainan dengan latihan bahasa

5. Permainan dengan lagu dan irama

Permainan tradisional memiliki karakteristik yaitu dengan menggunakan alam sekitar sebagai sumber bermain dan juga sebagai sumber alat permainan yang didukung kemampuan serta kreativitas dalam menggunakan bahan yang ada di lingkungan sekitar, permainan tradisional ini memiliki keutamaan yaitu mengutamakan interaksi sosial terutama dalam bekerja sama, kekompakan, saling asah asih asuh, sama dan melatih emosi serta moral anak. (Perdani).

Efek psikologis yang muncul pada saat anak-anak melakukan permainan tradisional ini adalah menyenangkan (enjoyable), relaksasi (relaxing), spontan (spontaneous), dan humoris. Hambatanhambatan pelaksanaan permainan tradisional adalah pemahaman orang tua dan guru yang kurang mendukung yang menganggap bermain merupakan hal sepele, atau terapi bermain hanya diperuntukan bagi mereka yang bermasalah (Nurgiansah, 2021).

Inovasi baru mengenai permainan 
tradisional merupakan hal yang sangat diperlukan karena tanpa adanya inovasi baru di era digital seperti sekarang maka permainan tradisional bisa jadi benarbenar terlupakan. Terdapat salah satu contoh permainan tradisional yang saat ini ditampilkan menggunakan media digital yaitu permainan congklak yang tergabung dalam satu aplikasi game umum bernama Hago.

Inovasi tersebutlah yang dibutuhkan pada era digital (Dewantara \& Nurgiansah, 2021b) (Dewantara et al., 2021), kita harus dapat mengembangkan ide-ide mengenai permainan tradisional da harus dapat mengemas permainan tradisional agar terlihat lebih menarik sehingga anak-anak akan mulai tertarik dan memainkan kembali permainan yang sudah ada sejak dulu bahkan turun temurun. Dalam hal ini guru dan masyarakat sekitar perlu berpartisipasi agar salah satu budaya tradisional kita dapat tetap bertahan dan juga terlestarikan dengan baik sehingga di masa yang akan datang, anak-anak dapat ikut mencoba dan mengetahui budaya yang dimiliki oleh bangsa kita tidak berhenti hanya pada kita saja.

Permainan tradisional merupakan salah satu dari berbagai kebudayaan yang tersisihkan. Penyebab tersisihnya permainan tradisional ini ialah kemajuan teknologi di era global yang cukup pesat sehingga membawa konsekuensi pada kemajuan berbagai hal termasuk permainan bagi anak, oleh karena itu masyarakat harus mendukung kebudayaan dan juga menjaga serta melestarikan dan mengembangkan kebudayaan tradisional tersebut (Nurgiansah, 2020). Permainan tradisional merupakan salah satu budaya bangsa dan juga aset bangsa yang perlu dilestarikan dan dikembangkan tentunya hal ini tidak lepas dari usaha untuk meningkatkan jiwa nasionalisme anak.

\section{KESIMPULAN}

Nasionalisme merupakan kesadaran bernegara atau semangat nasionalisme yang meningkatkan rasa kebanggaan terhadap negara, nasionalisme negara kita akhir-akhir ini mengalami kemerosotan karena adanya globalisasi. Permainan tradisional merupakan salah satu dari banyaknya kebudayaan yang dimiliki oleh negara kita yang mulai dilupakan kehadirannya, maka dari itu kita harus dapat mempertahankan kebudayaan tersebut dengan melestarikan dan memainkan kembali permainan tradisional agar keberadaan nya tidak punah, kita dapat melestarikannya dengan memainkannya kembali serta melakukan variasi agar kebudayaan kita tidak punah.

\section{DAFTAR PUSTAKA}

Artobatama, I. (2018). Pembelajaran stem berbasis outbound permainan tradisional. Indonesian Journal of Primary Education., 2(2), 40-47.

Bella, R., Gujali, A. I., Dewi, R. S., Lion, E., \& Maryam, M. (2021). Sistem Masyarakat dan Organisasi Suku Dayak Ngaju (Studi Kasus di Desa Mandomai Kalimantan Tengah). Jurnal Kewarganegaraan, 5(2), 364-375.

Chilwanto, E., Safna, S., Mutiara, M., Rahmad, G., Offeny, O., \& Saefulloh, A. (2021). Upacara Mamapas Lewu (Studi Kasus di Kota Kasongan Kalimantan Tengah). Jurnal Kewarganegaraan, $5(2)$, 374-354. https://journal.upy.ac.id/index.php/pkn/article/view/1673/pdf

Dewantara, J. A., \& Nurgiansah, T. H. (2021a). Peningkatan Keaktifan Belajar Melalui Penerapan Model Picture And Picture Dalam Pembelajaran PPKn di Sekolah Dasar. Jurnal Publikasi Pendidikan, 11(3), 234-241. 
Dewantara, J. A., \& Nurgiansah, T. H. (2021b). Strengthening Pancasila Values During the Covid-19 Pandemic. Edukatif: Jurnal Ilmu Pendidikan, 3(4), 2411-2417.

Dewantara, J. A., Nurgiansah, T. H., \& Rachman, F. (2021). Mengatasi Pelanggaran Hak Asasi Manusia dengan Model Sekolah Ramah HAM (SR-HAM). Edukatif: Jurnal Ilmu Pendidikan, 3(2), 261-269.

Dewi Sarah, S., Julita, S., Yowisa Yolanda, P., Nurtia Indah, S., Risa, S., \& Yohana, M. (2021). Peranan Pemerintah Desa dalam Pembangunan Infrastruktur. Jurnal Kewarganegaraan, 5(2), 295-302. https://doi.org/10.26418/j-psh.v12i1.46323

Febriyanti, N., \& Dewi, D. A. (2021). Pengembangan Nilai Moral Peserta Didik dalam Pembelajaran Pendidikan Kewarganegaraan. Jurnal Kewarganegaraan, 5(2), 476-482. https://journal.upy.ac.id/index.php/pkn/article/view/1772

Hikmah, S. N., \& Dewi, D. A. (2021). Meninjau Sejauh Mana Implementasi Nilai Pendidikan Karakter Melalui Pendidikan Kewarganegaraan di Perguruan Tinggi. Jurnal Kewarganegaraan, 5(2), 417-425. https://journal.upy.ac.id/index.php/pkn/article/view/1745

Isnaini, P. N., \& Dewi, D. A. (2021). Upaya Menerapkan Nilai-Nilai Pancasila Di Masa Pandemi $\begin{array}{lll}\text { Covid-. Jurnal Kewarganegaraan, } & \text { 322), }\end{array}$ https://journal.upy.ac.id/index.php/pkn/article/view/1344

Nurgiansah, T. H. (2018). Pengembangan Kesadaran Hukum Berlalu Lintas Siswa Melalui Model Pembelajaran Jurisprudensial Dalam Pendidikan Kewarganegaraan (Studi Kasus di SMK Bina Essa Kabupaten Bandung Barat Kelas X Administrasi Perkantoran). Tesis. Repository Universitas Pendidikan Indonesia, Oktober. http://ieeeauthorcenter.ieee.org/wp-content/uploads/IEEE-Reference-

Guide.pdf\%0Ahttp://wwwlib.murdoch.edu.au/find/citation/ieee.html\%0Ahttps://doi.or g/10.1016/j.cie.2019.07.022\%0Ahttps://github.com/ethereum/wiki/wiki/White-

Paper\%0Ahttps://tore.tuhh.de/hand

Nurgiansah, T. H. (2020). Filsafat Pendidikan. In Banyumas: CV Pena Persada.

Nurgiansah, T. H. (2021). Pendidikan Pancasila. In Solok: CV Mitra Cendekia Media.

Nurgiansah, T. H., \& Al Muchtar, S. (2018). Development of Student Awareness through Student Learning Model Jurisprudential in Citizenship Education. ATLANTIS PRESS, 251(Acec), 670-674. https://doi.org/10.2991/acec-18.2018.150

Pertiwi, S. G., \& Hidayah, Y. (2021). Implementasi Pendidikan Hak Asasi Manusia dalam Dunia Pendidikan Sekolah Dasar. Jurnal Kewarganegaraan, 5(2), 376-380. https://journal.upy.ac.id/index.php/pkn/article/view/1717

Rachman, F., Nurgiansah, T. H., \& Kabatiah, M. (2021). Profilisasi Pendidikan Kewarganegaraan dalam Kurikulum Pendidikan Indonesia. Edukatif: Jurnal Ilmu Pendidikan, 3(5), 2970-2984.

Rachman, F., Ryan, T., Kabatiah, M., Batubara, A., Pratama, F. F., \& Nurgiansah, T. H. (2021). Pelaksanaan Kurikulum PPKn pada Kondisi Khusus Pandemi Covid-19. Jurnal Basicedu, 5(6), 5682-5691.

Setyawati, Y., Septiani, Q., Aulia Ningrum, R., \& Hidayah, R. (2021). Imbas Negatif Globalisasi terhadap Pendidikan di Indonesia. Jurnal Kewarganegaraan, 5(2), 306-315. https://docplayer.info/214608960-Imbas-negatif-globalisasi-terhadap-pendidikan-diindonesia.html

Sofiyatul, N., \& Dewi, A. (2021). SKKP BAWASLU Sebagai Sarana Pendidikan Politik dalam Upaya meningkatkan Partisipasi Politik Warga Negara. Jurnal Kewarganegaraan, 5(2), 355-363. 
Ulfah, N., Hidayah, Y., \& Trihastuti, M. (2021). Urgensi Etika Demokrasi di Era Global: Membangun Etika dalam Mengemukakan Pendapat bagi Masyarakat Akademis Melalui Pendidikan Kewarganegaraan. Jurnal Kewarganegaraan, 5(2), 329-346. https://journal.upy.ac.id/index.php/pkn/article/view/1576 